\title{
Research on Control Algorithm of Proton Exchange Membrane Fuel Cell Cooling System
}

\author{
Tiancai Ma ${ }^{1,2, *(\mathbb{D} \text {, Weikang Lin }}{ }^{1,2}$, Yanbo Yang ${ }^{1,2}$, Ming Cong ${ }^{1,2}$, Zhuoping $\mathrm{Yu}^{1,2}$ and \\ Qiongqiong Zhou ${ }^{3,4}$ \\ 1 Clean Energy Automotive Engineering Center, Tongji University, Shanghai 201804, China; \\ weikang.lin@tongji.edu.cn (W.L.); yanboyang@tongji.edu.cn (Y.Y.); 1810557@tongji.edu.cn (M.C.); \\ yuzhuoping@tongji.edu.cn (Z.Y.) \\ 2 School of Automotive Studies, Tongji University, Shanghai 201804, China \\ 3 School of Economics and Management, Beihang University, Beijing 100191, China; zhouqq@most.cn \\ 4 National Science and Technology Infrastructure Center, Ministry of Science and Technology of the People's \\ Republic of China, Beijing 100862, China \\ * Correspondence: matiancai@tongji.edu.cn; Tel.: +86-21-6958-3814
}

Received: 19 August 2019; Accepted: 25 September 2019; Published: 27 September 2019

\begin{abstract}
The proton exchange membrane fuel cell (PEMFC) is taken to be the ultimate technical direction of vehicle power. Cooling system is a key component which directly affects the fuel cell performance, reliability and durability. For the purpose of keeping accurate temperature control under dynamic loads and achieving rapid warm-up control during cold-start, a $35 \mathrm{~kW}$ PEMFC's cooling system dynamic model is established and validated by experiments firstly. According to the simulation results, the model can well be fitted to the actual system. Then an integrate separate PID (Proportional-Integral-Derivative) algorithm and cooling fan prestart strategy is proposed. The result shows that it can effectively reduce the temperature overshoot under dynamic loads. In view of the thermostat mechanical characteristics tend to cause large temperature fluctuation during warm-up process, a thermostat control strategy is proposed to reduce the temperature fluctuation from $7.5{ }^{\circ} \mathrm{C}$ to $0.4{ }^{\circ} \mathrm{C}$.
\end{abstract}

Keywords: proton exchange membrane fuel cell; cooling system; modeling and simulating; control strategy

\section{Introduction}

The proton exchange membrane fuel cell (PEMFC) has attracted much attention in recent years because of its low operating temperature, fast start-up speed and high energy density [1,2]. However, in order for the PEMFC system to be more widely used, its durability problem must be solved [3]. Working temperature directly affects the fuel cell performance, reliability and durability $[4,5]$. Therefore, cooling system should decrease temperature fluctuations under dynamic loads and reduce warm-up time.

For the purpose of achieving the goal of effective cooling, four cooling techniques have been explored when researching this problem. The first is cooling with heat spreaders [6]. To maintain the stack temperature at an optimum value, Lopez-Sabiron et al. calculated the needed air flow with a simple one-dimensional model [7]. The second is cooling with separate air flow. Shahsavari et al. reduced the cost by developing an air-cooled fuel cell system that combines a cooling function with a cathode flow field [8]. The third is cooling with liquid. Soupremanien et al. cooled down the PEMFC by using a fluid in boiling conditions [9]. The fourth is cooling with phase change. To solve the non-isothermal two-phase flow problem, comprehensive multi-dimensional steady-state models have been established [10-12]. In general, liquid cooling is currently the most common method for high power fuel cell systems, due to its high heat transfer efficiency and compact structure. 
Great strides have already been taken to achieve the goal of effective cooling on models and control strategies. For model applications, Saygili et al. achieved the cooling target for a $3 \mathrm{~kW}$ PEMFC with semi-empirical model features by using a closed loop water circulation system [13]. Vasu et al. achieved the temperature prediction by building a lumped parameter model in a $5 \mathrm{~kW}$ fuel cell stack $[14,15]$. A capillary pumped loop system was adapted to fuel cell stacks over $50 \mathrm{~W}$ to well control thermal [16]. Hu et al. proposed a fuzzy control strategy with a $100 \mathrm{~W}$ fuel cell dynamic model which can be used to multi-parameter predictive control [17]. Considering the effect of fan power and pressure drop on overall performance of the open cathode air-cooled PEMFC, a two-dimensional numerical model was developed to investigate the forced air convection heat transfer [18]. Yu and Jung developed a two-dimensional heat transfer model to study temperature distribution in cell active area. And the parasitic losses of the pump and fan were calculated [19]. For an automobile thermal management system, Rokni and Rabbani researched the influence of the cooling water pump and radiator with fan [20]. A novel thermal control scheme for PEMFC generators was proposed [21].

For control strategy applications, Vega-Leal et al. used a proportional controller to control the fan speed according to the actual and desired temperature of the stack [22]. A model reference adaptive algorithm (MRAC) was proposed to improve the stability and convergence of temperature control [23]. Based on a simplified system at different stack loads, Liso et al. carried out a feedback PID (Proportional-Integral-Derivative) control in the research of fuel cell energy balance [24]. Chen et al. investigated the feasibility of nonlinear feedforward and LQR (Linear Quadratic Regulator) state feedback for temperature control [25]. A thermal management model was proposed under different working conditions to keep the output performance of PEMFC stable [26]. There is a large volume of research concerning the cooling control strategy [27-32].

In this work, a method which can keep accurate temperature control under dynamic loads, achieve target temperature under dynamic target temperatures and achieve rapid warm-up control during cold-start for PEMFC's cooling system is proposed. First, an entire cooling system model of PEMFC is established and validated by experiments in Section 2. According to the simulation results, the model can well be fitted to the actual system. Then, in Section 3, temperature control algorithms are developed for better performance of the system. Finally, experimental results collected from the test bench are shown in Section 4 .

\section{Modeling}

Fuel cell system mainly consists of fuel cell stack, the balance of plant (BOP) system and DC/DC converter. The BOP system includes hydrogen supply system, air supply system, cooling system and control system. The cooling system plays an important role in controlling the temperature of fuel cell stack. The main components include water pump, radiator, fan, thermostat, water tank, sensors and the corresponding pipeline. Figure 1 shows the main structure of the cooling system in this paper.

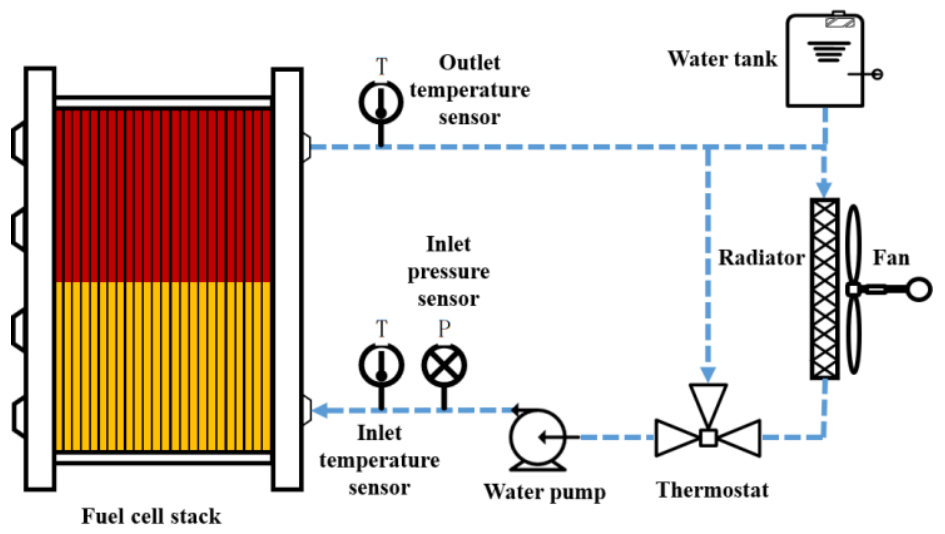

Figure 1. Diagram of fuel cell cooling system. 


\subsection{Model of Fuel Cell}

The dynamic model of the open system of the fuel cell stack can be determined by (1):

$$
C_{s t} M_{s t} \frac{d T_{s t}}{d t}=Q_{s t}-Q_{w}-Q_{r c}-Q_{v a p},
$$

where $C_{s t}$ is the heat capacity of the stack $\left(\mathrm{J} \cdot \mathrm{kg}^{-1} \cdot \mathrm{K}^{-1}\right)$, which is replaced by the heat capacity of the bipolar plate, $M_{s t}$ is the quality of the stack $(\mathrm{kg}), T_{s t}$ is the temperature of the stack $(\mathrm{K}), Q_{s t}$ is the heat generated by the stack (W), $Q_{w}$ is the heat taken away by the coolant $(\mathrm{W}), Q_{r c}$ is the heat taken away by the heat radiation and heat conduction of the stack $(\mathrm{W}), Q_{v a p}$ is the heat taken away by the vaporization of the product $(\mathrm{W})$.

Ignoring heat radiation, heat conduction and heat taken away by the water vaporization, the coolant outlet temperature is taken as the stack temperature, so the above equation can be simplified as:

$$
T_{s t, o u t}\left(t+t_{s}\right)=\int \frac{Q_{s t}-Q_{w}}{C_{s t} M_{s t}} d t,
$$

where $t_{s}$ is the delay time when the temperature of the stack changes.

Since the generated liquid water is little, it is considered to use a low calorific value as the output energy of a single cell. The equivalent voltage at low calorific value is $1.25 \mathrm{~V}$. Considering that $1.25 \mathrm{~V}$ is the theoretical value obtained when the generated water is in a gaseous state, the actual situation may be that liquid water is generated. Therefore, this part is multiplied by the proportional coefficient $k_{s t}$ to compensate the heat generated by the stack. According to the knowledge of thermodynamics,

$$
Q_{s t}=n_{\text {cell }} I_{s t}\left(1.25-E_{s t} / n_{\text {cell }}\right) k_{s t},
$$

where $n_{\text {cell }}$ is the number of cells, $E_{s t}$ is the total output voltage $(\mathrm{V})$ of the fuel cell and $I_{s t}$ is the total output current (A) of the fuel cell.

The heat taken away by the coolant is:

$$
Q_{w}=c_{q, w} \dot{m} \dot{m}_{w}\left(T_{s t, o u t}-T_{s t, i n}\right),
$$

where $c_{q, w}$ is the constant pressure specific heat capacity of the coolant $\left(\mathrm{J} \cdot \mathrm{kg}^{-1} \cdot \mathrm{K}^{-1}\right), \dot{m}_{w}$ is the mass flow rate of the coolant $\left(\mathrm{kg} \cdot \mathrm{s}^{-1}\right), T_{s t, o u t}$ is the coolant outlet heap temperature $(\mathrm{K})$ and $T_{s t, i n}$ is the coolant inlet heap temperature (K).

The fuel cell stack on the actual system is tested. Figure 2 shows its polarization curve. Table 1 shows the parameters of the fuel cell system.

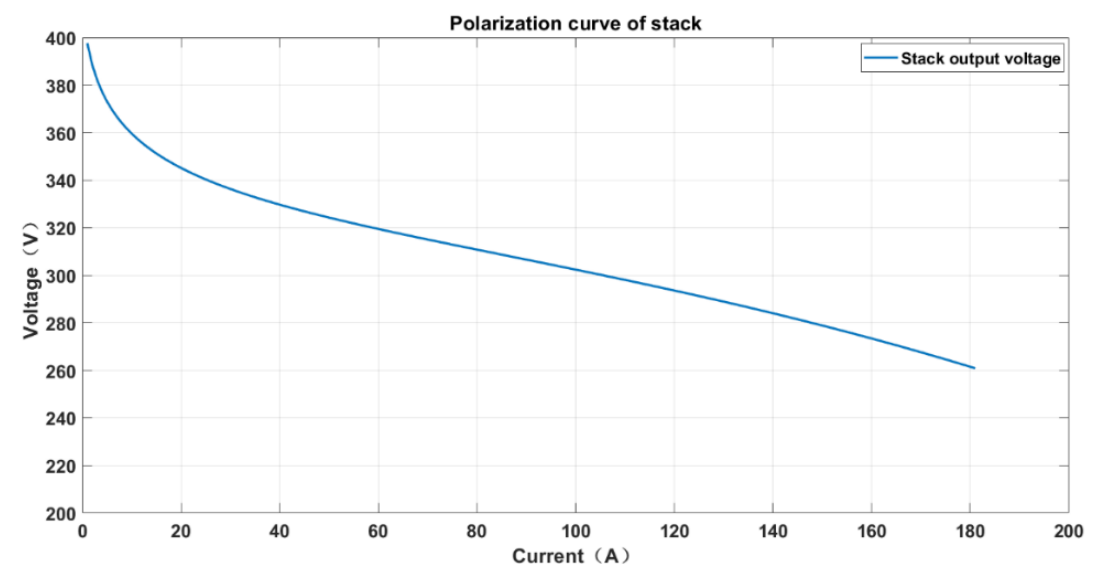

Figure 2. Polarization curve of the fuel cell stack. 
Table 1. Fuel cell system parameters.

\begin{tabular}{cc}
\hline Name & Value \\
\hline Brand of fuel cell stack & POWERCELL S2 Series \\
Material of Bipolar plate & Stainless steel \\
Number of cells in fuel cell stack & 432 pieces \\
Coolant category & Deionized water \\
Coolant density & $1000 \mathrm{~kg} \cdot \mathrm{m}^{-3}$ \\
Specific heat capacity of coolant at constant & $4200 \mathrm{~J} \cdot \mathrm{kg}^{-1} \cdot \mathrm{K}^{-1}$ \\
pressure & $31 \mathrm{~kg}$ \\
Stack mass & $500 \mathrm{~J} \cdot \mathrm{kg}^{-1} \cdot \mathrm{K}^{-1}$ \\
Ambient temperature & $30{ }^{\circ} \mathrm{C}$ \\
\hline
\end{tabular}

\subsection{Model of Pump}

In the cooling system, the role of the pump is to overcome the flow resistance to ensure that the coolant takes away excess heat from the fuel cell stack. The coolant circuit is an open system. The inlet pressure of the pump can be approximated as a fixed value $108 \mathrm{kPa}$.

By adjusting the pump PWM duty cycle, the relationship between pump outlet pressure and flow can be fitted by the following equations:

$$
\begin{aligned}
& \dot{m_{w}}=\frac{\rho}{1000+60}\left(k_{p_{1}} * D_{\text {pump }}^{2}+k_{p_{2}} * D_{\text {pump }}\right), \\
& P_{\text {pump }, \text { out }}=k_{p_{3}} * D_{\text {pump }}^{2}+k_{p_{4}} * D_{\text {pump }}+k_{p_{5}},
\end{aligned}
$$

where $D_{\text {pump }}$ is the PWM duty cycle of the pump, $k_{p_{i}}$ is the fitting factor and $P_{\text {pump }, \text { out }}$ is the pump outlet pressure $(\mathrm{kPa})$.

Figure 3 shows the flow and pressure fitting curves of the pump.

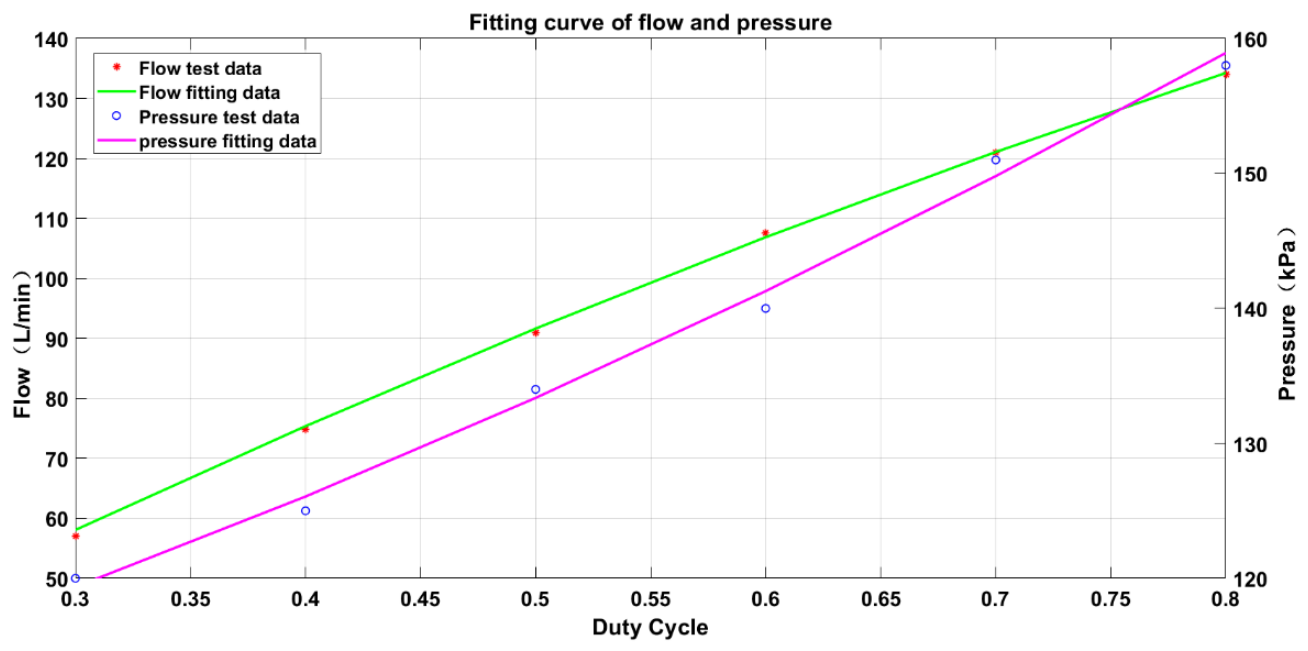

Figure 3. The flow and pressure fitting curves of the pump.

\subsection{Model of Radiator}

At normal operating conditions, the coolant flow rate only needs to be adjusted within a small range. So, the radiator has a great influence on the temperature of the fuel cell system.

According to the thermodynamic properties, the heat dissipation of the radiator can be calculated by the equation:

$$
Q_{\text {rad }}=K * S * \Delta T \text {, }
$$


where $Q_{\text {rad }}$ is the heat dissipation power $(\mathrm{W}), K$ is the heat transfer coefficient of the radiator $\left(\mathrm{W} \cdot \mathrm{m}^{2} \cdot \mathrm{k}^{-1}\right)$, $\Delta T$ is the heat dissipation temperature difference on both sides of the radiator $(\mathrm{K})$ and $S$ is the effective heat transfer area of the radiator $\left(\mathrm{m}^{2}\right)$.

In this paper, the test data of the radiator is analyzed and the experimental data is fitted to build the radiator model. Three cooling fans are selected as the power sources of radiator and air heat exchange. The effective duty cycle of a single fan ranges from $10 \%$ to $90 \%$ and the total duty cycle of three fans ranges from $30 \%$ to $270 \%$. Assuming that the fan output performance is consistent, the radiators are tested by changing the fan duty cycle and cooling power. The obtained test data are shown in Figures 4 and 5.

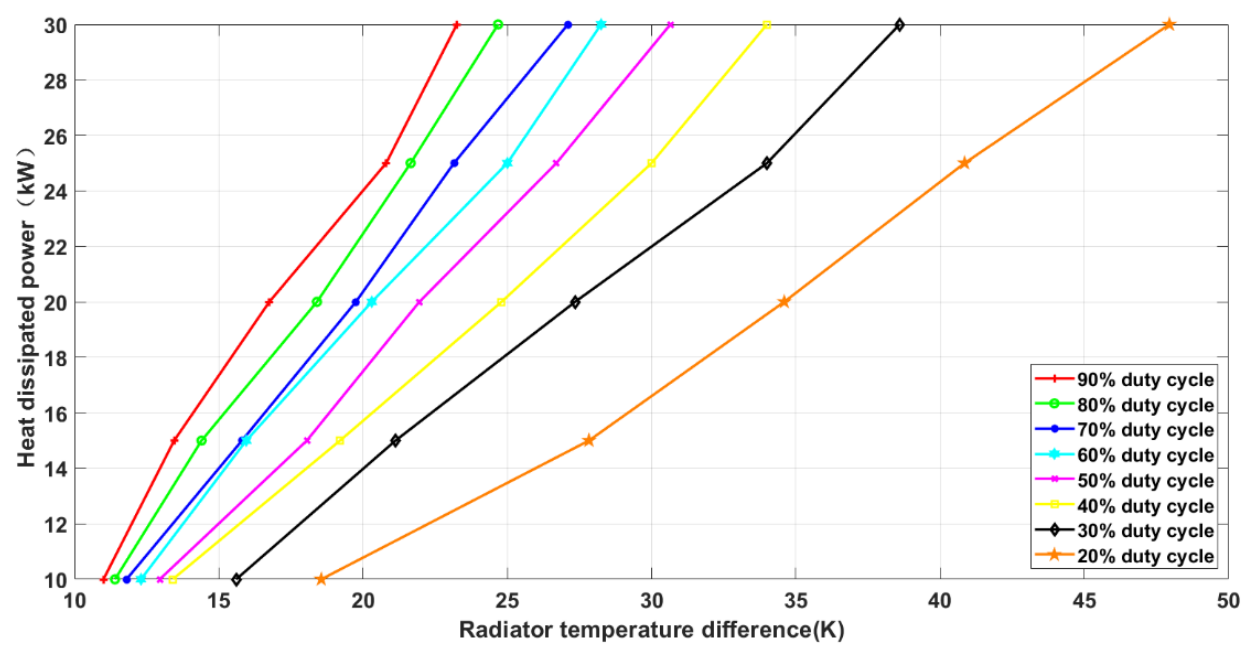

Figure 4. Relationship between radiator temperature difference and heat dissipation power.
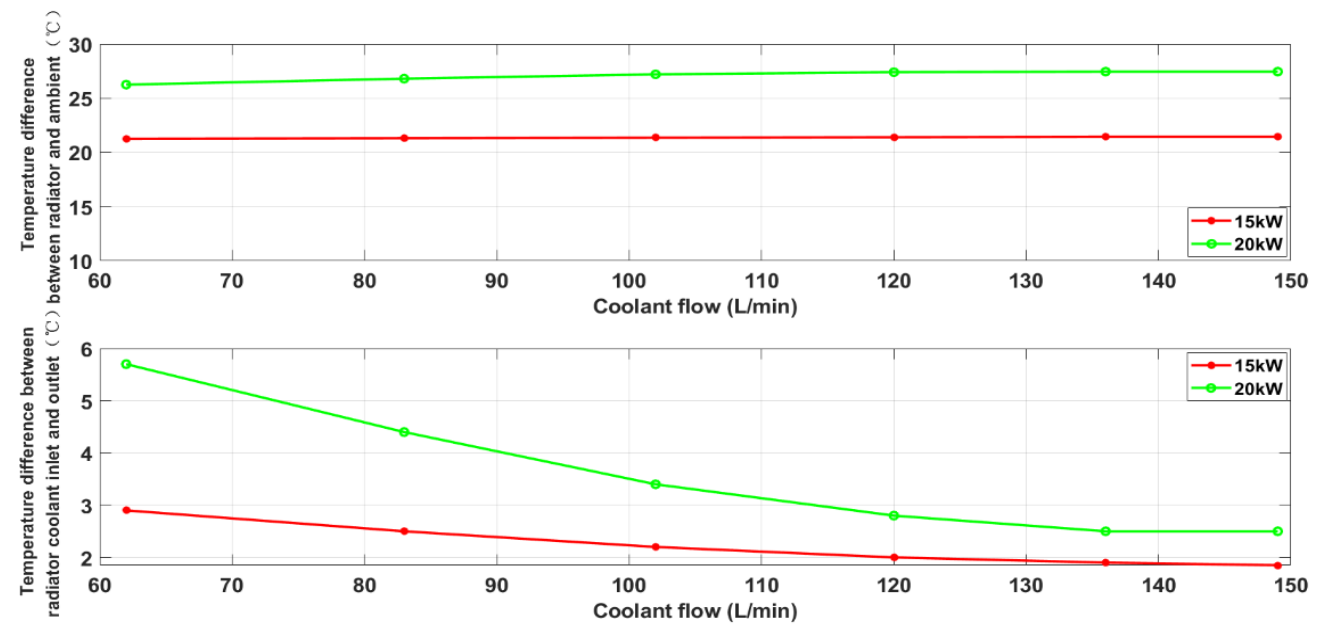

Figure 5. Relationship between heat dissipation related parameters and coolant flow rate.

Figure 4 shows that the relationship between the heat dissipation power and the temperature difference is basically consistent with the theory of heat dissipation, which is linear. When the temperature difference is constant, the heat dissipation increases with the increase of the opening degree of the cooling fan. When the heat dissipation is constant, the heat dissipation temperature difference becomes smaller as the opening degree of the cooling fan increases. Figure 5 shows the coolant flow has little effect on the heat dissipation and it mainly affects the temperature difference between the radiator inlet and outlet.

In summary, the heat dissipation capability of the radiator is fitted using the following mathematical model: 


$$
\begin{gathered}
T_{\text {rad }}=\left(T_{\text {rad }, \text { out }}+T_{\text {rad,in }}\right) / 2, \\
\Delta T=T_{\text {rad }}-T_{a m b,}, \\
Q_{\text {rad }}=k_{1} * \Delta T *\left[k_{2} * e^{k_{3} * D_{f a n}}+k_{4} * e^{k_{5} * D_{f a n}}\right], \\
T_{\text {rad,out }}=T_{\text {rad,in }}-\frac{Q_{\text {rad }}}{\dot{m}_{w} c_{p, w}},
\end{gathered}
$$

where $T_{\text {rad }}$ is the temperature of the radiator $(\mathrm{K}), T_{\text {rad,out }}$ is the coolant temperature of the radiator outlet (K), $T_{\text {rad,in }}$ is the coolant temperature of the radiator inlet $(\mathrm{K})$ and $T_{a m b}$ is the ambient temperature (radiator air side inlet temperature) $(\mathrm{K}), \Delta T$ is the temperature difference between the radiator and the ambient $(\mathrm{K}), D_{f a n}$ is the cooling fan duty cycle, $\dot{m}_{w}$ is the coolant mass flow $\left(\mathrm{kg} \cdot \mathrm{s}^{-1}\right)$ and $c_{p, w}$ is the specific heat capacity of the coolant at constant pressure $\left(\mathrm{J} \cdot \mathrm{kg}^{-1} \cdot \mathrm{K}^{-1}\right), k_{i}$ is the fitting coefficient.

\subsection{Moedel of Thermostat}

The thermostat can achieve fuel cell rapid warm-up. A small cycle is adopted to ensure the coolant bypass the radiator. After reaching a certain temperature, the valve gradually opens and the low-temperature coolant is mixed into the radiator to keep the temperature steady and continuously rising to the optimal working temperature. The thermostat used in this system is a wax thermostat. The working parameters are shown in Table 2.

Table 2. Thermostat parameters.

\begin{tabular}{ccc}
\hline Physical Characteristics & Electrical Characteristics & Pipeline Interface \\
\hline $\begin{array}{c}\text { Opening temperature: } 55^{\circ} \mathrm{C}-60{ }^{\circ} \mathrm{C} ; \\
\text { Full open temperature: } 65{ }^{\circ} \mathrm{C}\end{array}$ & $\begin{array}{l}\text { Working voltage: } 9 \mathrm{~V}-36 \mathrm{~V} ; \\
\text { Duty cycle adjustment range: } 5 \%-95 \%\end{array}$ & $38 \mathrm{~mm}-25 \mathrm{~mm}-38 \mathrm{~mm}$ \\
\hline
\end{tabular}

\subsection{Model Validation}

In the actual system, different fuel cell output current is set by VCU (Vehicle Control Unit). The coolant flow is controlled by adjusting the water pump to drive the PWM. The PWM is driven by the fan so that the temperature of the fuel cell stack inlet coolant is about $70^{\circ} \mathrm{C}$. The coolant temperature at the outlet of the stack can be measured on the actual system. Based on the MATLAB/Simulink model, the simulation test is carried out. The coolant temperature of the stack inlet is set to $70{ }^{\circ} \mathrm{C}$ and the coolant flow is $2.23 \mathrm{~kg} \cdot \mathrm{s}^{-1}$. The relationship between fuel cell inlet and outlet coolant temperature and output current of the stack in the actual system is shown in Table 3.

Table 3. The relationship between fuel cell inlet and outlet coolant temperature and output current.

\begin{tabular}{ccccc}
\hline $\begin{array}{c}\text { Output Current } \\
\text { (A) }\end{array}$ & $\begin{array}{c}\text { Inlet Temperature } \\
\left({ }^{\circ} \mathbf{C}\right)\end{array}$ & $\begin{array}{c}\text { Actual Outlet } \\
\text { Temperature }\left({ }^{\circ} \mathbf{C}\right)\end{array}$ & $\begin{array}{c}\text { Simulation Outlet } \\
\text { Temperature }\left({ }^{\circ} \mathbf{C}\right)\end{array}$ & Error (\%) \\
\hline 70 & 70 & 72 & 72.05 & 0.07 \\
80 & 70 & 72.5 & 72.41 & -0.12 \\
90 & 70 & 72.7 & 72.75 & 0.07 \\
100 & 70 & 72.9 & 73.13 & 0.32 \\
110 & 70 & 73.3 & 73.52 & 0.30 \\
120 & 70 & 73.6 & 73.87 & 0.37 \\
130 & 70 & 74.3 & 74.25 & -0.07 \\
\hline
\end{tabular}

According to the comparison between the actual data and the simulation data, the maximum error calculated is $0.37 \%$. It can be seen that the thermodynamic model of the stack has high precision and can well reflect the temperature change process of the fuel cell system. 


\section{Control Algorithm}

There are many kinds of temperature control algorithms but the PID control algorithm is widely used due to it has a low dependence on the accuracy of the model [13]. The fuel cell system has the characteristics of large inertia and long delay time. Conventional PID adjustment is controlled according to temperature changes and it is difficult to overcome the large overshoot caused by the inertia of temperature. Therefore, overshoot is an important consideration in control algorithms. The heat production power of the stack affects the temperature change of the stack. The heat power generated by the stack is directly related to the output current, the output voltage and the number of cells. For a particular fuel cell system, the output characteristics of the stack and the number of cells are definite. Therefore, it is necessary to perform a certain compensation of the controlled value according to the fluctuation of the current, thereby achieving the purpose of overcoming overshoot.

\subsection{Integral Separation PID Algorithm}

In this paper, a compensating integral separation PID control algorithm is designed. The heat production of the stack is calculated based on a simplified mathematical model of the stack. According to the heat dissipation at the temperature balance, the difference between the given duty cycle and the actual duty cycle is calculated, so as to compensate the PID output and roughly adjusting the temperature. Finally, the temperature is precisely adjusted by PID. The control flow chart of the algorithm is shown in Figure 6.

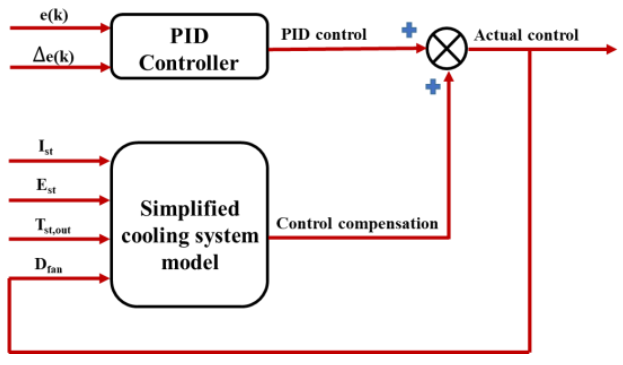

Figure 6. Flow chart of compensation PID (Proportional-Integral-Derivative) control algorithm.

Specific steps are as follows:

1. Integral separation

The integration part can eliminate the steady-state error and increase the accuracy of the control system. In the start and end process, the deviation is too large, which causes the integral operation to exceed the limit value, causing a large overshoot. Therefore, the integral is usually separated in the PID control. The specific method is:

The threshold of the deviation $(\varepsilon)$ is set according to the actual system control requirements. The coefficient $(\alpha)$ is introduced. When the system deviation is relatively large, $|e(t)| \geq \varepsilon$, PD control is adopted, $\alpha=0$. When the system deviation is relatively small, $|e(t)|<\varepsilon$, PID control is adopted, $\alpha=1$. Then put this coefficient into the discrete PID control equation to get:

$$
u(t)=K_{p} e(k)+K_{i} \alpha \sum_{j=0}^{k} e(j)+K_{d}[e(k)-e(k-1)] .
$$

2. Calculate the compensation output

In practical applications, calculating the heat dissipation by using the exponential calculation in Equation (11) increases the complexity. In order to simplify the design and retain certain accuracy, Taylor expansion is considered to be used and the first term is taken:

$$
e^{k x}=1+k x
$$


Then Equation (11) can be simplified as:

$$
Q_{\text {rad }}=k_{1} * \Delta T *\left[k_{2} *\left(1+k_{3} D_{f a n}^{\prime}\right)+k_{4} *\left(1+k_{4} D_{f a n}^{\prime}\right)\right] .
$$

The compensation can be obtained:

$$
D_{\text {comp }}=D_{f a n}^{\prime}-D_{f a n} .
$$

In the case of small current fluctuations, PID can maintain the output at the set value according to its own adjustment, so the compensation mainly acts on the case where the output current changes greatly. 3. Tuning of PID parameters

A two-dimensional table is constructed based on $e(k)$ and $\Delta e(k)$ and the interval is controlled and divided. Then, based on the model simulation parameters, the PID parameters are adjusted according to the changing rules of the actual system.

4. Calculation of control output

The final output is obtained by adding the discrete PID output and the compensation output:

$$
D_{f a n}=K_{p} e(k)+K_{i} \alpha \sum_{j=0}^{k} e(j)+K_{d}[e(k)-e(k-1)]+\sum D_{\text {comp }} .
$$

The coolant temperature of the stack inlet is used as a control target for stable temperature control. In general, the optimum inlet temperature of fuel cell stack is $60-80^{\circ} \mathrm{C}$, the optimal outlet temperature is $65-85^{\circ} \mathrm{C}$ and the difference of inlet and outlet temperature is $5-10{ }^{\circ} \mathrm{C}$. According to the fuel cell datasheet, the target inlet temperature setting is $70^{\circ} \mathrm{C}$ in this paper. And the maximum overshoot temperature is expected to be $\pm 2{ }^{\circ} \mathrm{C}$. Take $5 \mathrm{~A}$ as the current change threshold to compensate the controlled variable. Since it takes time to pull down the load, the current change is determined every $5 \mathrm{~s}$ as the time interval. Table 4 shows the PID parameters in controller.

Table 4. PID parameters.

\begin{tabular}{ccccc}
\hline $\boldsymbol{e}(\boldsymbol{k})$ & $\boldsymbol{\Delta} \boldsymbol{e}(\boldsymbol{k})$ & $\boldsymbol{K}_{\boldsymbol{p}}$ & $\boldsymbol{K}_{\boldsymbol{i}}$ & $\boldsymbol{K}_{\boldsymbol{d}}$ \\
\hline$|e(k)| \geq 1$ & $\geq 0$ & 2 & 0 & 1 \\
$0.5 \leq|e(k)|<1$ & $<0$ & 2 & 0 & 0 \\
$0 \leq|e(k)|<0.5$ & $<0$ & 3 & 0 & 1 \\
& $<0$ & 3 & 0 & 0 \\
& $<0$ & 4 & 0.001 & 1 \\
\hline
\end{tabular}

\subsection{Fan Prestart Algorithm}

Since the fan causes a current surge, the fan controller performs a corresponding soft start. Test the performance of the fan to get a delay of about $5 \mathrm{~s}$ from the start. If the stack maintains a constant current start, due to the influence of negative integral accumulation and temperature inertia, the overshoot is bound to be too large. As can be seen from the Figure $7 \mathrm{a}$, the overshoot is $2.5^{\circ} \mathrm{C}$. Therefore, the fan startup needs to be processed. According to the radiator model, when the heat dissipation temperature difference is $45^{\circ} \mathrm{C}$, all three fans are $10 \%$ open and the heat dissipation power is about $20 \mathrm{~kW}$. Assuming that each fan has the same heat dissipation capability, each fan has a cooling power of $6.6 \mathrm{~kW}$. Set the fan prestart power range from $5 \mathrm{~kW}$ to $10 \mathrm{~kW}$ and the current range is 20-40 A according to Equation (3). Therefore, to overcome the effects of fan startup, the fan prestart duty cycle is set to $10 \%$ and the temperature setting rules are shown in Figure $7 \mathrm{~b}$. 

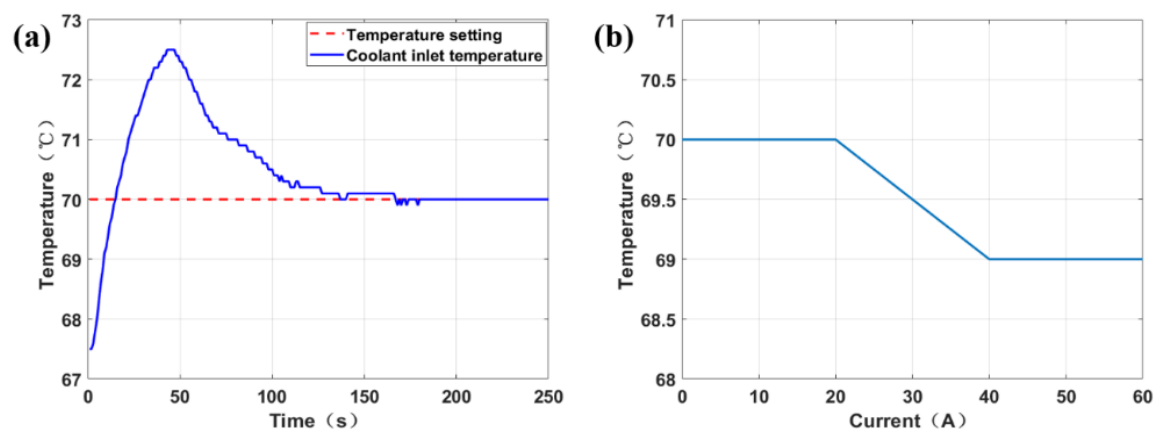

Figure 7. Cooling system temperature without fan prestart (a). With fan prestart (b).

\subsection{Rapid Warm-up Control During Cold-Start}

The fuel cell stack is configured with small cycles during startup to quickly reach optimal operating temperatures. However, opening the valve during the cycle switching can cause abrupt changes in temperature and pressure, which can adversely affect the performance of the stack. In this paper, the electronic thermostat is adjusted to reduce this adverse effect.

\subsubsection{The Thermostat Performance Calibration}

Performance tests are performed on the test bench for the thermostat at different water temperatures $\left(35-55{ }^{\circ} \mathrm{C}\right)$ with different duty cycle outputs $(10 \%-55 \%)$. The thermostat opening is defined as the ratio of flow in the large cycle to total flow:

$$
o_{t}=\frac{\dot{m}_{l}}{\dot{m}_{t}}=\frac{\dot{m}_{t}-\dot{m_{s}}}{\dot{m}_{t}}
$$

where $o_{t}$ is the thermostat opening, $\dot{m}_{s}$ is the small circulation flow $\left(\mathrm{L} \cdot \mathrm{min}^{-1}\right), \dot{m}_{l}$ is the large circulation flow $\left(\mathrm{L} \cdot \mathrm{min}^{-1}\right)$ and $\dot{m}_{t}$ is the total circulation flow $\left(\mathrm{L} \cdot \mathrm{min}^{-1}\right)$.

The output flow of the thermostat with different duty cycle is assigned at different coolant temperatures. According to Equation (17) and flow distribution, the variation of thermostat opening is shown in Figure 8.
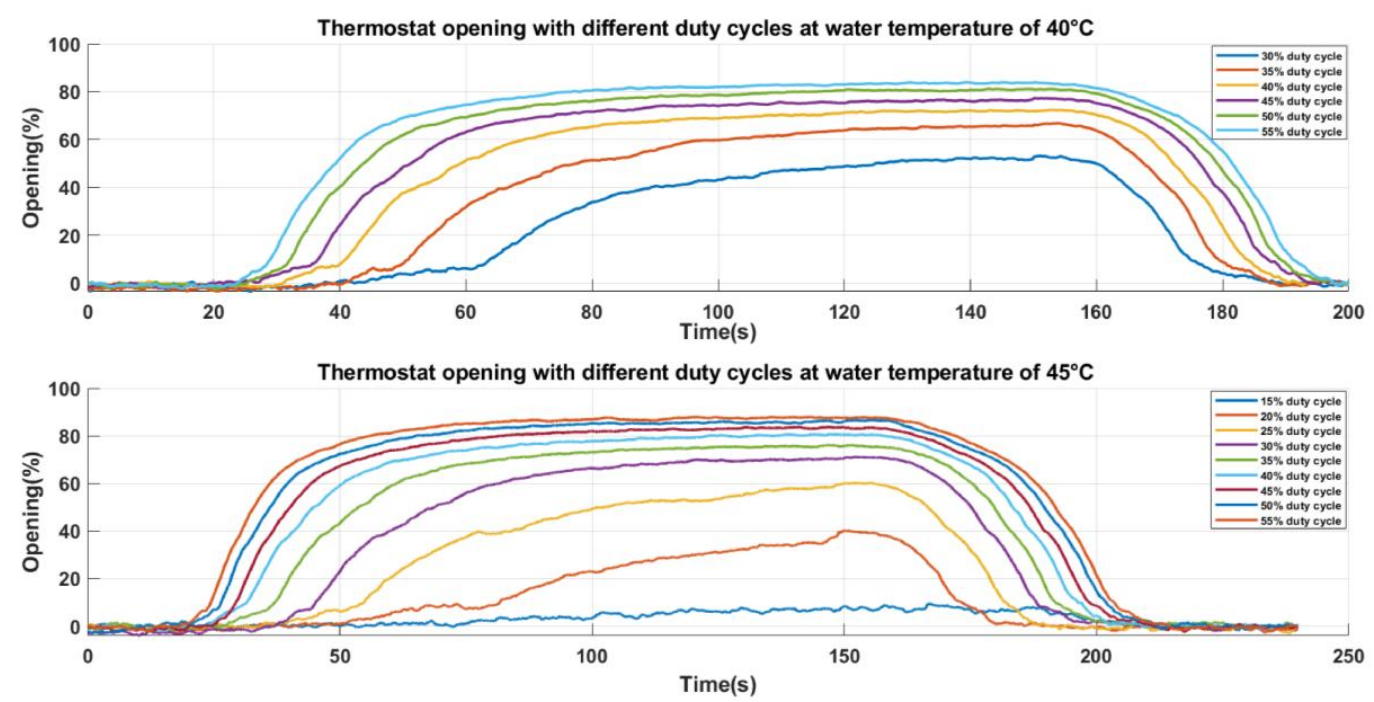

(a)

Figure 8. Cont. 

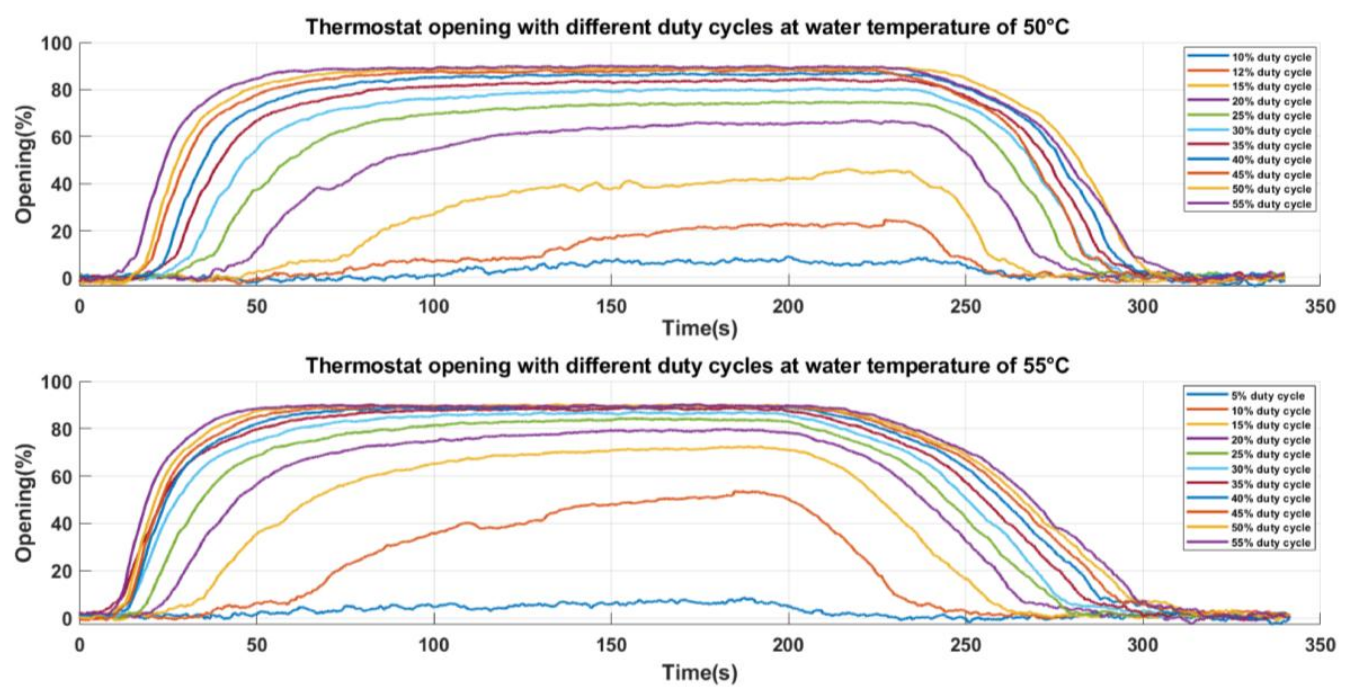

(b)

Figure 8. Thermostat opening change under different conditions. (a): $40-45^{\circ} \mathrm{C}$; (b): $50-55^{\circ} \mathrm{C}$.

\subsubsection{The Thermostat Open Algorithm}

Combined with the dynamic performance diagram of the thermostat, it can be seen that at $55^{\circ} \mathrm{C}$, when the duty cycle is given $30 \%$, the thermostat opening can be considered to be close to the full value. At temperatures below $50{ }^{\circ} \mathrm{C}$, the dynamic performance of the thermostat is unstable, with a delay time of up to $25 \mathrm{~s}$ at $40^{\circ} \mathrm{C}$, which is extremely unfavorable for control. According to the data sheet, the thermostat has a mechanical characteristic at $55-60{ }^{\circ} \mathrm{C}$ and can reach the full value at about $65^{\circ} \mathrm{C}$. In order to reduce the coupling relationship between mechanical properties and electronic properties, electronic control is selected at $50-60^{\circ} \mathrm{C}$.

At $50^{\circ} \mathrm{C}$, the thermostat startup has a delay of nearly $10 \mathrm{~s}$ and the thermostat opening varies greatly with the same duty cycle of $50-55^{\circ} \mathrm{C}$. Therefore, at $50^{\circ} \mathrm{C}$, the thermostat must be preheated with power in advance. Based on the above discussion, the control strategy of thermostat is shown in Figure 9.

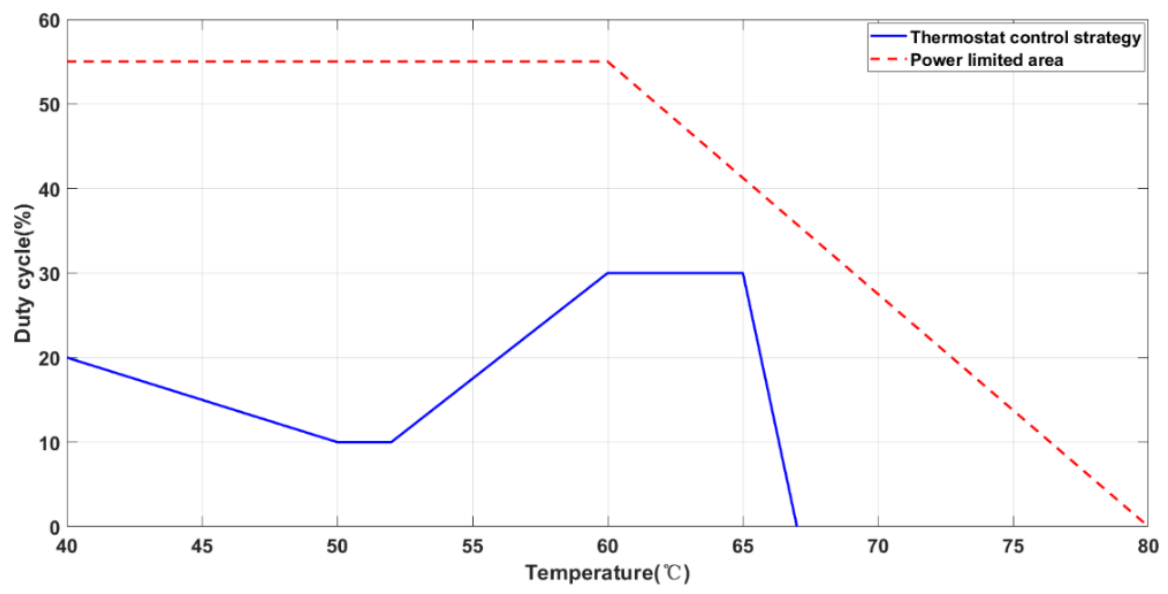

Figure 9. Thermostat control strategy.

\section{Result and Discussion}

In order to validate the control algorithm. A $35 \mathrm{~kW}$ fuel cell system test bench was established and a self-designed embedded controller is used as the control system. The validity of the control algorithm 
is verified by three experiments. Figure 10 shows the $35 \mathrm{~kW}$ fuel cell system test bench. Table 1 shows the parameters of the fuel cell system. Table 5 shows the parameters of the control system.

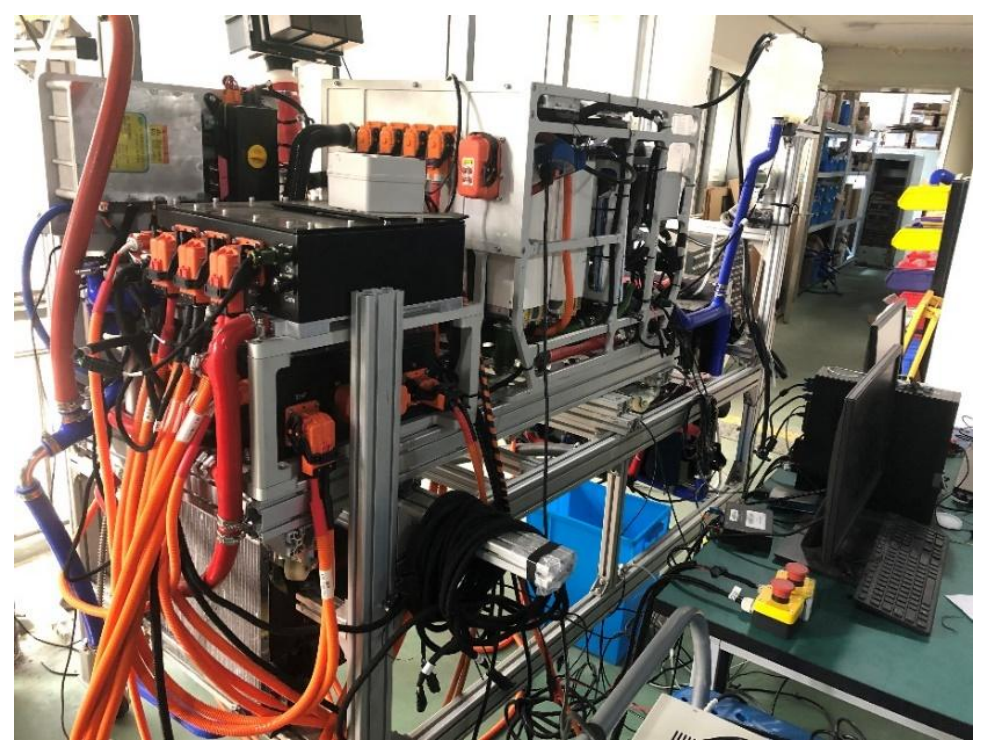

Figure 10. Thirty-five $\mathrm{kW}$ fuel cell system test bench.

Table 5. Control system parameters.

\begin{tabular}{ccc}
\hline FCU (Fuel Cell Control Unit) & Item & Description \\
\hline & Brand of master control chip & NXP MPC5746R \\
& Brand of Compiler & WINDRIVER \\
& Brand of Debugger & LAUTERBACH LA-300 \\
& Software development kit & NXP_MCAL \\
& Software development platform & Matlab/Simulink \\
\hline
\end{tabular}

\subsection{Accurate Temperature Control Under Dynamic Loads}

To verify the feasibility of the control algorithm under dynamic loads, an experiment was conducted. The target fuel cell inlet temperature is $70^{\circ} \mathrm{C}$. The fuel cell output current increases from 60 A to $120 \mathrm{~A}$ in 10 A steps.

Figure 11 shows the current, fuel cell temperature and fan opening data. In general, the temperature fluctuation is relatively small and the temperature is relatively stable. According to the first 500 seconds data, it can be seen that the fan opening is frequently adjusted to meet the control requirements when the temperature has just reached the target temperature. According to the first 3000 seconds data, it only allows 2 fans when the output current under $90 \mathrm{~A}$, due to the minimum fan opening is $15 \%$. So, the three fans must not work in sync under small loads. In addition, it can be seen that the number of opening of each fan is relatively average under heavy loads.

Figure 12 shows a partial enlarged view. As the current increases, the temperature changes within $0.6^{\circ} \mathrm{C}$, which is relatively stable. As can be seen from the experimental data, the prestart of the fan effectively slows down the rate of temperature rise at the start of the stack. 


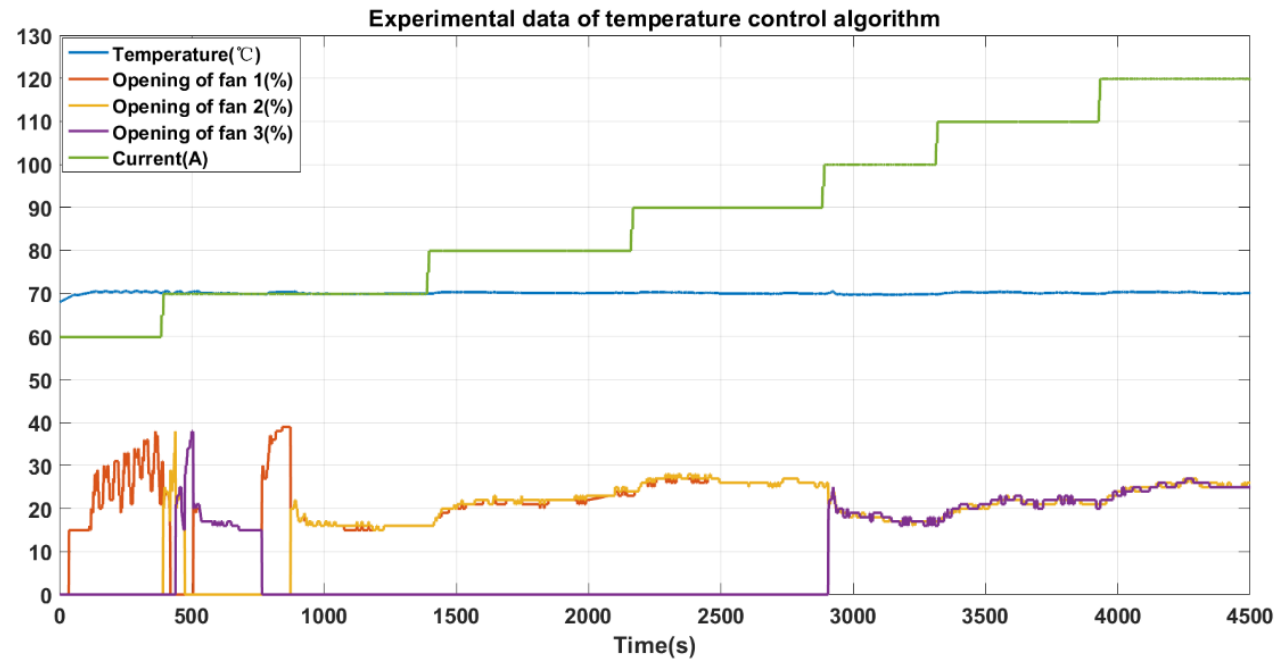

Figure 11. Experiment data under dynamic loads.

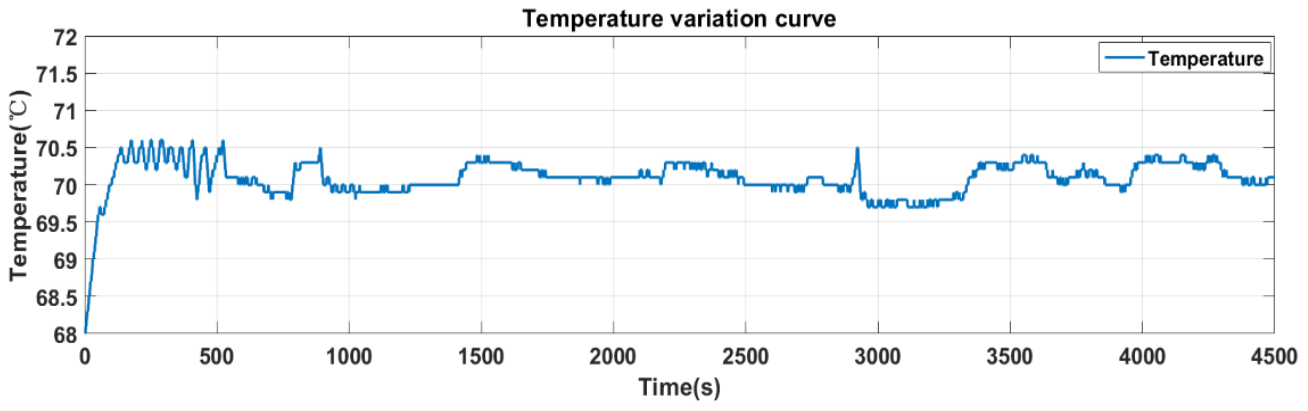

Figure 12. Temperature curve under dynamic loads.

\subsection{Accurate Temperature Control Under Dynamic Target Temperatures}

To verify the feasibility of the control algorithm under dynamic target temperature, an experiment was conducted. The target fuel cell output current is $120 \mathrm{~A}$. The fuel cell target temperature is $72{ }^{\circ} \mathrm{C}, 70$ ${ }^{\circ} \mathrm{C}, 65^{\circ} \mathrm{C}, 60{ }^{\circ} \mathrm{C}, 65^{\circ} \mathrm{C}, 70{ }^{\circ} \mathrm{C}, 72{ }^{\circ} \mathrm{C}$.

Figure 13 shows the current, fuel cell temperature and fan opening data. According to the test data, if the target temperature decrease $5{ }^{\circ} \mathrm{C}$, the opening of fan will increase rapidly to excrete excess heat. And the opening of fan will decrease rapidly when the temperature is close to the target. If the target temperature increases $5{ }^{\circ} \mathrm{C}$, the fan will close to wait for warming to the target value. The target temperature will not be changed frequently in a specific fuel cell. So, the temperature can achieve target value rapidly in practice by use this control algorithm. 


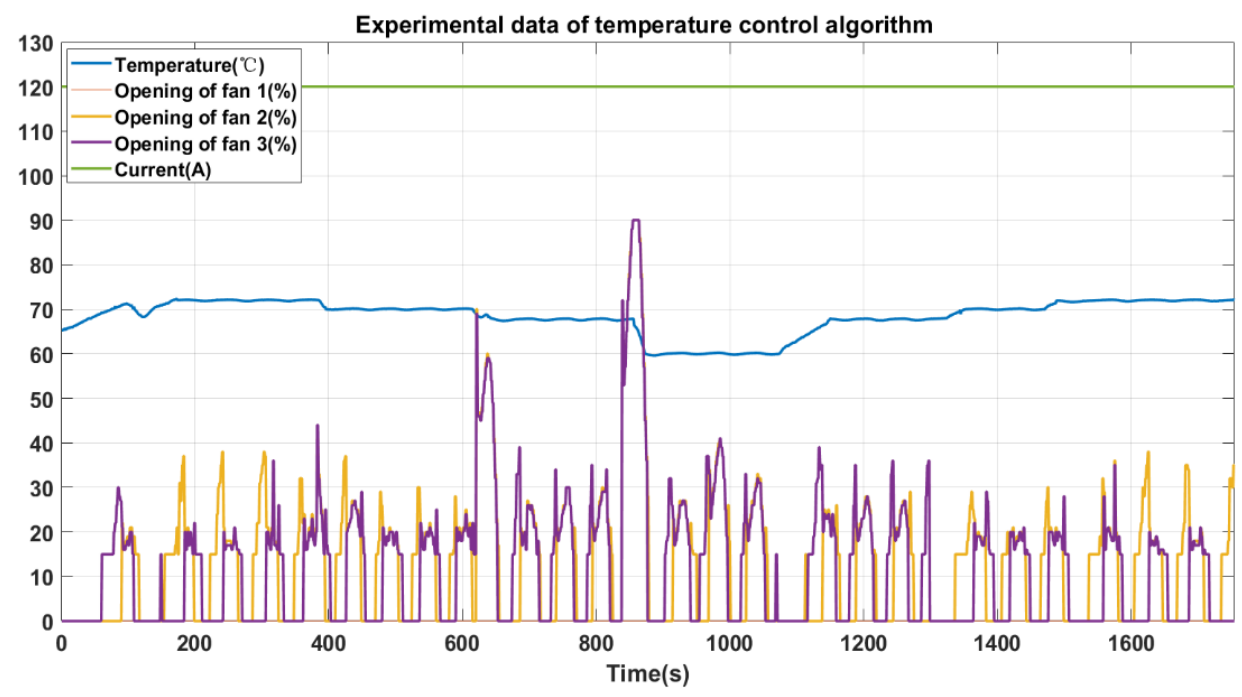

Figure 13. Experiment data under dynamic target temperatures.

\subsection{Rapid Warm-up Control During Cold-Start}

The control strategy of thermostat open algorithm is also applied to the controller. A group of comparative experiments were conducted in the actual system. Figure 14 shows the test results when only the mechanical characteristics are used and the thermostat electronic characteristics are enabled.

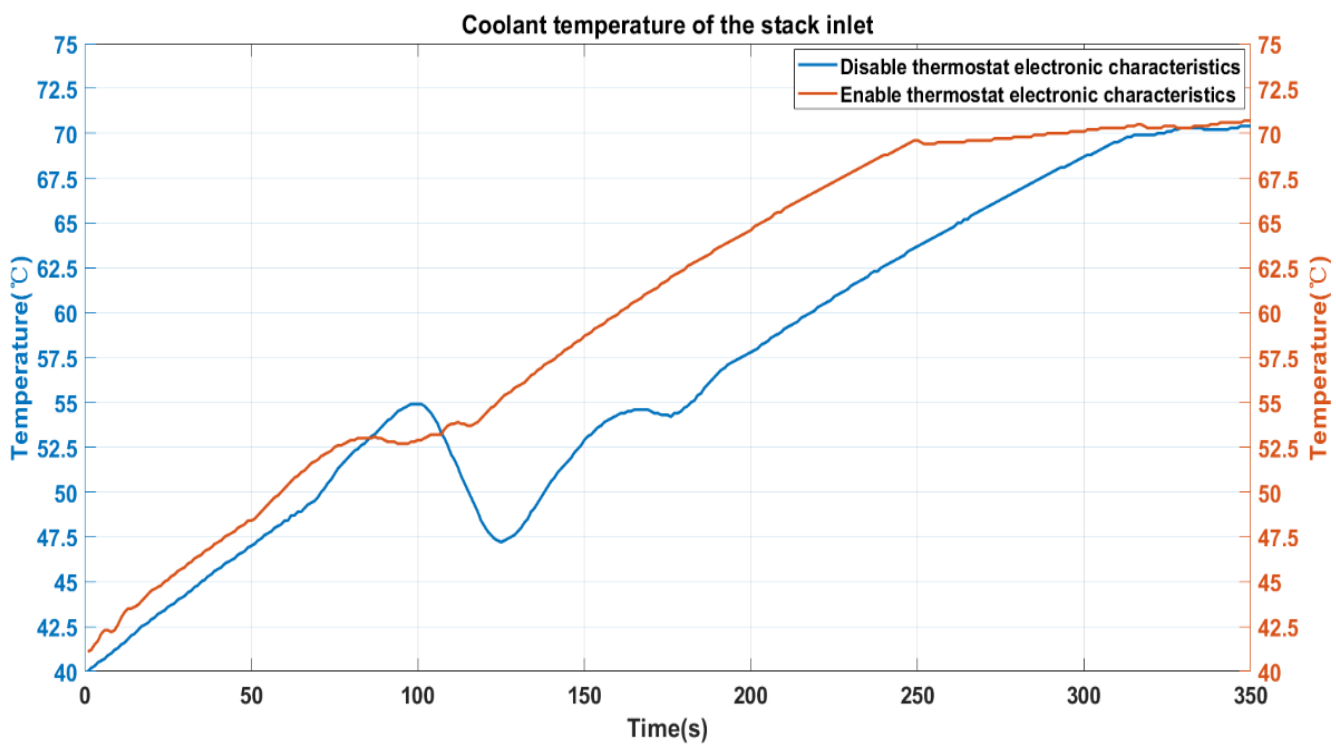

Figure 14. Enable thermostat electronic characteristics. Disable thermostat electronic characteristics.

It can be seen from the comparison of the above two figures that if the electronic characteristics of the thermostat are disabled, the temperature will fluctuate greatly, dropping by about $7.5^{\circ} \mathrm{C}$. If the thermostat is electronically controlled using the above control strategy, the temperature fluctuation is about $0.4{ }^{\circ} \mathrm{C}$. When the temperature up to $55^{\circ} \mathrm{C}$, the mechanical valve will open rapidly. Too much cold water enters the fuel cell and causes the temperature drop. The valve opening speed can be lowered through the control algorithm. According to the comparison results, this control strategy effectively reduces the temperature fluctuation of the coolant of the stack inlet.

\section{Conclusions}

Temperature control is a key which directly affects the fuel cell performance, reliability and durability. In this paper, a $35 \mathrm{~kW}$ PEMFC's cooling system dynamic model is established firstly. Then 
an integrate separate PID algorithm and cooling fan prestart strategy is proposed. The result shows that it can effectively reduce the temperature overshoot under dynamic loads and achieve target temperature under dynamic target temperatures. In view of the thermostat mechanical characteristics tend to cause large temperature fluctuation during warm-up process, a thermostat control strategy is proposed to reduce the temperature fluctuation from $7.5^{\circ} \mathrm{C}$ to $0.4^{\circ} \mathrm{C}$. The experiments results show that this control algorithm can keep accurate temperature control under dynamic loads and achieve rapid warm-up control during cold-start.

Author Contributions: Conceptualization, T.M., W.L. and Z.Y.; Data curation, W.L.; Funding acquisition, T.M. and Z.Y.; Methodology, W.L.; Project administration, T.M. and Z.Y.; Formal analysis, T.M. and W.L.; Investigation, W.L.; Resources, T.M. and Z.Y.; Software, W.L.; Supervision, T.M. and Z.Y.; Validation, W.L.; Visualization, W.L.; Writing—original draft, T.M. and W.L.; Writing—review \& editing, Y.Y., M.C. and Q.Z.

Funding: This research was funded by the National Natural Science Foundation of China (NSFC, No. 51876144) and the National key research and development program (Fuel Cell Engine Integration and Control for Heavy Truck).

Conflicts of Interest: The authors declare no conflict of interest. The funders had no role in the design of the study; in the collection, analyses, or interpretation of data; in the writing of the manuscript, or in the decision to publish the results.

\section{References}

1. Anderson, R.; Zhang, L.; Ding, Y.; Blanco, M.; Bi, X.; Wilkinson, D.P. A critical review of two-phase flow in gas flow channels of proton exchange membrane fuel cells. J. Power Sources 2010, 195, 4531-4553. [CrossRef]

2. Hu, G.; Fan, J.; Chen, S.; Liu, Y.; Cen, K. Three-dimensional numerical analysis of proton exchange membrane fuel cells (PEMFCs) with conventional and interdigitated flow fields. J. Power Sources 2004, 136, 1-9. [CrossRef]

3. Wu, J.; Yuan, X.Z.; Martin, J.J.; Wang, H.; Zhang, J.; Shen, J.; Wu, S.; Merida, W. A review of PEM fuel cell durability: Degradation mechanisms and mitigation strategies. J. Power Source 2008, 184, 104-119. [CrossRef]

4. Liu, Z.; Zhang, H.; Wang, C.; Mao, Z. Numerical simulation for rib and channel position effect on PEMFC performances. Int. J. Hydrogen Energy 2010, 35, 2802-2806. [CrossRef]

5. Strahl, S.; Husar, A.; Puleston, P.; Riera, J. Performance Improvement by Temperature Control of an Open-Cathode PEM Fuel Cell System. Fuel Cells 2014, 14, 466-478. [CrossRef]

6. Zhang, G.; Kandlikar, S.G. A critical review of cooling techniques in proton exchange membrane fuel cell stacks. Int. J. Hydrog. Energy 2012, 37, 2412-2429. [CrossRef]

7. López-Sabirón, A.M.; Barroso, J.; Roda, V.; Barranco, J.; Lozano, A.; Barreras, F. Design and development of the cooling system of a $2 \mathrm{~kW}$ nominal power open-cathode polymer electrolyte fuel cell stack. Int. J. Hydrog. Energy 2012, 37, 7289-7298. [CrossRef]

8. Shahsavari, S.; Desouza, A.; Bahrami, M.; Kjeang, E. Thermal analysis of air-cooled pem fuel cells. Int. J. Hydrog. Energy 2012, 37, 18261-18271. [CrossRef]

9. Soupremanien, U.; Le Person, S.; Favre-Marinet, M.; Bultel, Y. Tools for designing the cooling system of a proton exchange membrane fuel cell. Appl. Therm. Eng. 2012, 40, 161-173. [CrossRef]

10. Siegel, N.P.; Ellis, M.W.; Nelson, D.J.; Spakovsky, M.R.V. A two-dimensional computational model of a PEMFC with liquid water transport. J. Power Source 2004, 128, 173-184. [CrossRef]

11. Sivertsen, B.R.; Djilali, N. CFD-based modelling of proton exchange membrane fuel cells. J. Power Source 2005, 141, 65-78. [CrossRef]

12. Wang, Y.; Wang, C.Y. A Nonisothermal, Two-Phase Model for Polymer Electrolyte Fuel Cells. J. Electrochem. Soc. 2006, 153, A1193-A1200. [CrossRef]

13. Saygili, Y.; Eroglu, I.; Kincal, S. Model based temperature controller development for water cooled PEM fuel cell systems. Int. J. Hydrog. Energy 2015, 40, 615-622. [CrossRef]

14. Vasu, G.; Tangirala, A.K. Control-orientated thermal model for proton-exchange membrane fuel cell systems. J. Power Sources 2008, 183, 98-108. [CrossRef]

15. Vasu, G.; Tangirala, A.K.; Viswanathan, B.; Dhathathreyan, K.S. Continuous bubble humidification and control of relative humidity of H2 for a PEMFC system. Int. J. Hydrog. Energy 2008, 33, 4640-4648. [CrossRef] 
16. Silva, A.P.; Galante, R.M.; Pelizza, P.R.; Bazzo, E. A combined capillary cooling system for fuel cells. Appl. Therm. Eng. 2012, 41, 104-110. [CrossRef]

17. Hu, P.; Cao, G.Y.; Zhu, X.J.; Hu, M. Coolant circuit modeling and temperature fuzzy control of proton exchange membrane fuel cells. Int. J. Hydrog. Energy 2010, 35, 9110-9123. [CrossRef]

18. Sasmito, A.P.; Lum, K.W.; Birgersson, E.; Mujumdar, A.S. Computational study of forced air-convection in open-cathode polymer electrolyte fuel cell stacks. J. Power Source 2010, 195, 5550-5563. [CrossRef]

19. Yu, S.; Jung, D. Thermal management strategy for a proton exchange membrane fuel cell system with a large active cell area. Renew. Energy 2008, 33, 2540-2548. [CrossRef]

20. Rabbani, A.; Rokni, M. Dynamic characteristics of an automotive fuel cell system for transitory load changes. Sustain. Energy Technol. Assess. 2013, 1, 34-43. [CrossRef]

21. Hwang, J.J. Thermal control and performance assessment of a proton exchanger membrane fuel cell generator. Appl. Energy 2013, 108, 184-193. [CrossRef]

22. Vega-Leal, A.P.; Palomo, F.R.; Barragán, F.; García, C.; Brey, J.J. Design of control systems for portable PEM fuel cells. J. Power Sources 2007, 169, 194-197. [CrossRef]

23. Han, J.; Yu, S.; Yi, S. Advanced thermal management of automotive fuel cells using a model reference adaptive control algorithm. Int. J. Hydrog. Energy 2017, 42, 4328-4341. [CrossRef]

24. Liso, V.; Nielsen, M.P.; Kær, S.K.; Mortensen, H.H. Thermal modeling and temperature control of a PEM fuel cell system for forklift applications. Int. J. Hydrog. Energy 2014, 39, 8410-8420. [CrossRef]

25. Cheng, S.; Fang, C.; Xu, L.; Li, J.; Ouyang, M. Model-based temperature regulation of a PEM fuel cell system on a city bus. Int. J. Hydrog. Energy 2015, 40, 13566-13575. [CrossRef]

26. Zhao, X.; Li, Y.; Liu, Z.; Li, Q.; Chen, W. Thermal management system modeling of a water-cooled proton exchange membrane fuel cell. Int. J. Hydrog. Energy 2015, 40, 3048-3056. [CrossRef]

27. Chang, H.; Duan, C.; Xu, X.; Pei, H.; Shu, S.; Tu, Z. Technical performance analysis of a micro- combined cooling, heating and power system based on solar energy and high temperature PEMFC. Int. J. Hydrog. Energy 2019, 44, 21080-21089. [CrossRef]

28. Shen, J.; Tu, Z.; Chan, S.H. Enhancement of mass transfer in a proton exchange membrane fuel cell with blockage in the flow channel. Appl. Therm. Eng. 2019, 149, 1408-1418. [CrossRef]

29. Pohjoranta, A.; Halinen, M.; Pennanen, J.; Kiviaho, J. Model predictive control of the solid oxide fuel cell stack temperature with models based on experimental data. J. Power Source 2015, 277, 239-250. [CrossRef]

30. Flückiger, R.; Tiefenauer, A.; Ruge, M.; Aebi, C.; Wokaun, A.; Büchi, F.N. Thermal analysis and optimization of a portable, edge-air-cooled PEFC stack. J. Power Source 2007, 172, 324-333. [CrossRef]

31. Wu, J.; Galli, S.; Lagana, I.; Pozio, A.; Monteleone, J.; Yuan, X.Z.; Martin, J.; Wang, H. An air-cooled proton exchange membrane fuel cell with combined oxidant and coolant flow. J. Power Source 2009, 188, 199-204. [CrossRef]

32. Andreasen, S.J.; Ashworth, L.; Remón, I.N.; Rasmussen, P.L.; Nielsen, M.P. Modeling and Implementation of a 1 kW, Air Cooled HTPEM Fuel Cell in a Hybrid Electrical Vehicle. ECS Trans. 2008, 12, 639-650. [CrossRef] 